Jurnal Ilmu Budaya, Vol. 17, No. 2 Februari Tahun 2021

\title{
PETA PERSEBARAN RANDAI DI KABUPATEN KUANTANSINGINGI, PROVINSI RIAU
}

\author{
Yulita Fitriana ${ }^{1,}$ Arpina $^{2}$, Irwanto $^{3}$ \\ ${ }^{123}$ Balai Bahasa Riau \\ Email: yulita.fitriana.bbpr@gmail.com ${ }^{1}$, arpinahasan@gmail.com ${ }^{2}$, \\ irwanto74@gmail.com ${ }^{3}$
}

\begin{abstract}
This study aims to describe the history and distribution of Randai, as well as making Randai's distribution maps in Kuantansingi Regency, Riau Province. This research is qualitative-descriptive. The data are obtained through field data and library data. Through this research it is known that the Randai of Kuantansingingi originally comes from Minangkabau and has undergone changes. The acculturation of Minangkabau culture with Malay and change of times has led to changes in stories, language, costumes, dances (joget), musical instruments, and when it is performed, even the view of people on Randai. In the process of making the Randai of Kuantansingingi's Map in Riau Province, 49 Randai groups were inventoried in various sub-districts in Kuantansingingi Regency. All these Randai groups have been mapped onto the Map of Kuantansingingi's Randai.
\end{abstract}

Keywords: map, randai, Kuantansingingi Regency

\section{Pendahuluan}

Kabupaten Kuantan Singingi merupakan salah satu dari dua belas kota/kabupaten yang ada di Provinsi Riau. Kabupaten ini beribukota Teluk Kuantan. Berdasarkan data Badan Pusat Statistik Kabupaten Kuantan Singingi (2020), wilayah kabupaten ini terletak pada posisi antara $0^{0} 00--1^{0} 00$
Lintang Selatan dan $101^{0} 02--101^{0} 55$ Bujur Timur. Di sebelah Selatan, kabupaten ini berbatasan dengan Provinsi Jambi, di Utara dengan Kabupaten Pelalawan dan Kabupaten Kampar. Adapun di Timur, Kabupaten Kuantan Singingi berbatasan dengan Kabupaten Indragiri Hulu, dan di Barat ada Provinsi Sumatera Barat. 
Jurnal Ilmu Budaya, Vol. 17, No. 2 Februari Tahun 2021

Berbatasan dengan beberapa
daerah tersebut ikut membentuk
budaya masyarakat di daerah ini.
Secara tidak langsung, Beradat ke
Pagaruyung dan Beraja ke Indragiri
merupakan bentuk pengakuan akan
pengaruh budaya Melayu dan
Minangkabau yang menghasilkan
budaya khas Kuantan Singingi.

Di Kabupaten ini dikenal berbagai tradisi lisan yang memperlihatkan adanya akulturasi kedua budaya tersebut, seperti yang terlihat di dalam tradisi masyarakat berupa pantun, kayat, dikieldikir (zikir), salawat dulang, ruda, nandong, ratik bajalan, koba, dan randai.

Randai merupakan salah satu budaya masyarakat Kuantan Singingi yang masih hidup dan berkembang dengan baik hingga saat ini. Berbagai capaian juga diraih berkenaan dengan tradisi ini. Pada 2019, bersama pacu jalur, randai mencetak prestasi dengan meraih rekor Museum Rekor Indonesia (MURI) sebagai Penari Randai Terbanyak dan Lomba Pacu Jalur Terbanyak. Sebelumnya, sebagai 
Jurnal Ilmu Budaya, Vol. 17, No. 2 Februari Tahun 2021

\begin{tabular}{lll}
\hline Penelitian mengenai randai & dalam "Transformasi Bujang Gadih At \\
sudah cukup banyak dilakukan. & Randai's Show Teluk Kuantan, \\
Hamidy (1980) pernah menulis tesis & Provinsi Riau”. \\
"Randai dalam Kehidupan Masyarakat & \multicolumn{1}{c}{ Setakat ini, dari berbagai } \\
Melayu Riau". Tesis Hamidy ini & penelitian berkaitan dengan Randai \\
membahas mengenai etimologi kata & Kuantan Singingi, belum ditemukan \\
randai, sejarah perkembangan randai, & penelitian randai yang dimaksudkan \\
dan pembahasan mengenai berbagai & untuk memetakan randai yang ada di \\
unsur randai sebagai sebuah karya & Kabupaten tersebut. Padahal, seperti \\
sastra. & yang disampaikan Asrif (2014:135) \\
Puswanto, Sriwulan, dan Martarosa & hasil pemetaan sastra lokal berguna \\
(2019) yang membahas musik randai & untuk penyusunan kebijakan nasional \\
dalam "Studi Analisis: Konsep & terkait dengan kebudayaan. Selain itu, \\
Musikal Randai Kuantan di Teluk & kegiatan pemetaan sastra akan \\
Kuantan-Riau melalui Teori Semiologi & menyediakan dokumentasi budaya \\
Musik". Selanjutnya, Sosiady dan & yang artikel sewaktu-waktu
\end{tabular}
Syah (2019) dalam “Analisis Promosi Randai (Warisan Budaya Tak Benda) sebagai Kegiatan Ekonomi Kreatif dalam Rangka Riau sebagai "Home Land Melayu" (Studi pada Randai Kuantan Baserah Kuantan Singingi) meneliti randai kaitannya dengan promosi ekonomi kreatif. Kemudian, Misrawati dan Sulaiman (2020) membahas transformasi karakter Bujang Gadi sebagai bagian dari hiburan dan pengajaran, dan salah satu identitas Randai Kuantan Singingi dimanfaatkan untuk kepentingan bangsa dan negara. Jufrizal (2018) menegaskan bahwa pemetaan dan kajian bahasa dan sastra daerah merupakan kerja ilmiah kebahasaan dan kesasteraan yang berkaitan dengan kebijakan.

Sesuai dengan sifatnya yang lisan, tradisi ini sangat mudah tergerus zaman. Pandangan sebagian masyarakat bahwa sastra lisan terkesan kuno terkadang membuat kepedulian masyarakat akan tradisi lisan 
berkurang. Pengaruh globalisasi yang memungkinkan pengaruh asing masuk dengan mudah ikut serta meminggirkan tradisi dari pikiran masyarakat. Oleh karena itu, perlu ada upaya untuk menginventarisasikan dan mendokumentasikan Randai Kuantan Singingi sebagai bagian dari upaya pelestarian budaya masyarakat Kuantan Singingi.

Berdasarkan masalah tersebut, tujuan penelitian ini adalah: a. Mendeskripsikan tradisi randai yang ada di Kabupaten Kuantan Singingi, Riau; dan b. Memetakan lokasi dan persebaran tradisi randai di Kabupaten Kuantan Singingi. Adapun penelitian ini bermanfaat sebagai berikut: a. Deskripsi tentang bentuk dan jenis randai serta persebarannya di Kabupaten Kuantansingingi dapat dijadikan sarana untuk menelusuri kekhasan jati diri orang Melayu Kuantan Singingi; b. Hasil inventarisasi randai ini dapat dipergunakan oleh para pengambil kebijakan untuk menentukan kebijakan yang tepat sasaran dalam rangka pelindungan randai sebagai salah satu hasil kebudayaan masyarakat Kuantan Singingi; dan c. Hasil pemetaan randai ini dapat dimanfaatkan oleh lembaga pendidikan untuk membuat bahan ajar berbasis kearifan lokal Melayu dan komunitas bahasa daerah Melayu.

\section{Metode Penelitian}

Penelitian ini bersifat kualitatifdeskriptif. Data yang dipergunakan adalah data lapangan dan data pustaka. Data lapangan didapat dengan turun langsung ke daerah pengamatan di Kabupaten Kuantan Singingi, yaitu: Desa Rantau Langsat (Kecamatan Kuantan Mudik), Desa Kopah (Kecamatan Kuantan Tengah), dan Cerenti (Kecamatan Cerenti). Adapun data sekunder didapatkan melalui "Laporan Inventarisasi Dinas Pariwisata dan Budaya Kabupaten Kuantan Singingi" yang dilakukan oleh Syaifuddin. Selain itu, data pustaka didapat melalui data tertulis, audio visual lainnya.

Pengambilan data dilakukan dengan teknik wawancara, rekam, dan catat. Wawancara dilakukan dengan panduan beberapa pertanyaan yang 
Jurnal Ilmu Budaya, Vol. 17, No. 2 Februari Tahun 2021

sudah dibuat sebelumnya. Wawancara

dilakukan terhadap informan:

Daryanto (52 tahun), Haji Saprin (80

tahun), Suparmi (45 tahun), Syafrizal

(70-an tahun) dan Syaifuddin (45

tahun). Mereka merupakan pemuka adat, pelaku tradisi, dan pengamat tradisi.

Pada saat pengolahan data, dilakukan klasifikasi dan identifikasi data. Setelah itu, data yang diperoleh ditelaah bentuk dan isi, lalu dideskripsikan. Persebaran randai Kuantan Singingi yang didapat dimasukkan ke dalam sebuah peta persebaran randai di Kabupaten Kuantan Singingi. Peta yang dipergunakan sebagai peta dasar merupakan adaptasi dari Peta Infrastruktur Kabupaten Kuantan Singingi yang diterbitkan oleh Departemen Pekerjaan Umum. Beberapa simbol yang tidak perlu, dihilangkan dari peta tersebut.

Dalam buku Pedoman Penelitian Pemetaan Sastra, Badan Pengembangan dan Pembinaan Bahasa menetapkan beberapa simbol untuk kegiatan pemetaan sastra, yaitu: simbol Tragedi (P), Komedi (Q), Melodrama (R), Tragikkomedi (S), Musikal (T), dan jenis yang lain (U). (Harimansyah, 2019). Di dalam penelitian ini, merujuk kepada bentuk randai yang diiringi musik, di dalamnya terdapat cerita melodrama, dan komedi, simbol yang digunakan adalah U (jenis yang lain). Dengan demikian, simbol yang dipergunakan di dalam peta adalah $U$ di dalam lingkaran merah. Akan tetapi, di peta, huruf $\mathrm{U}$ di dalam lingkaran merah tidak terlihat.

\section{Pembahasan}

\section{Sejarah Perkembangan Randai} Kuantan Singingi

Randai merupakan seni pertunjukan yang oleh Chairul Harun (dalam Wendy, 2014:38) disebutkan berasal dari kata andai. Di dalam bahasa Minangkabau, andai berarti 'perumpamaan'. Hal tersebut berkaitan dengan perumpamaan pertarungan dalam praktik pelatihan silek yang terdapat di dalam randai. 
Jurnal Ilmu Budaya, Vol. 17, No. 2 Februari Tahun 2021

Hamidy (1980:8) juga
menyebutkan bahwa randai berasal
dari kata berandai-andai
'diumpamakan atau dimisalkan'.
Hamidy berpendapat hal tersebut
berdasarkan pada permainan randai
yang para pemainnya memerankan
dirinya sebagai orang lain.

Randai Cindur Mato merupakan randai yang pertama yang ada di Kuantan Singingi. Para pemainnya adalah perantau Minangkabau dan orang Kampar (Kabupaten Kampar, Riau). Pertunjukan randai ini masih sama dengan pertunjukan randai yang ada di Minangkabau, Sumatera Barat. Ciri khas randai Minangkabau, seperti pemain mengenakan busana celana tapak itik, sesamping, dan salempang kain sarung. Cerita yang dibawakan berasal dari cerita kaba. Bahkan menurut Hidayat (2014), cerita Randai Kuantan Singingi juga dapat berasal dari cerita rakyat, seperti Cerita Dang Gedunai dan Niniak Jiruhun.

Dalam wawancara yang dilakukan dengan Suparmi pada 2019, perubahan cerita koba ke cerita kehidupan sosial khas Kuantan terjadi

sekitar 1989. Walaupun ditengarai, perubahan tersebut sudah terjadi jauh sebelumnya.

Kehidupan randai di Kabupaten Kuantan Singingi juga mengalami pasang surut. Menurut Muslim (2006) perubahan-perubahan itu terjadi karena pengaruh lingkungan dan waktu. Berdasarkan pendapat Hamidy (1980) dan Muslim (2006), proses perubahan itu terjadi dalam beberapa waktu. Waktu ini seolah membentuk beberapa tahapan perubahan. Pertama, pada tahun 1948-1949 (masa agresi Belanda), semangat nasionalisme masyarakat melawan Belanda ikut mengubah cerita randai yang awalnya berasal dari kaba menjadi cerita yang terjadi di lingkungan masyarakat Kuantan Singingi. Cerita Randai Sikum, misalnya, terinsiprasi dari cerita Sikum, seorang mata-mata Belanda yang dibunuh pejuang kemerdekaan. Kedua, diperkirakan pada 1951-1960, pertunjukan randai mengalami kemunduran. Kaum ulama menilai pertunjukan randai tersebut tidak sesuai dengan ajaran agama Islam. Selain itu, ada keprihatinan 
Jurnal Ilmu Budaya, Vol. 17, No. 2 Februari Tahun 2021

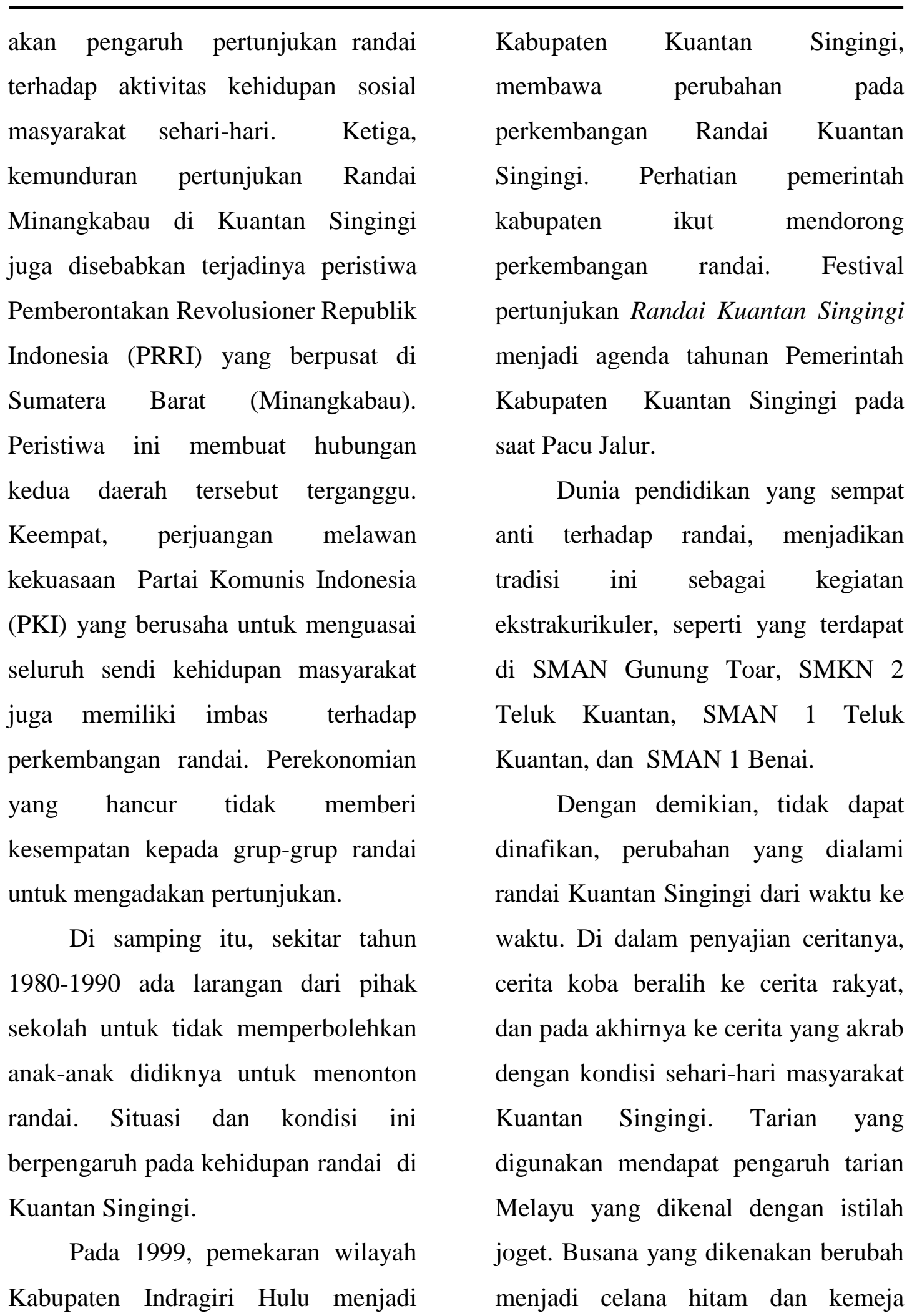


Jurnal Ilmu Budaya, Vol. 17, No. 2 Februari Tahun 2021

putih. Terkadang kostum yang

dipergunakan adalah pakaian Melayu, teluk belanga. Bahkan lagu-lagu yang

didendangkan pun sangat bervariasi.

Bahasa yang dipergunakan di dalam

dialog adalah bahasa Melayu dialek

Rantau Kuantan dan Singingi.

\section{Pertunjukan Randai Kuantan} Singingi

Pertunjukan randai ditampilkan dalam berbagai kegiatan masyarakat Kuantan Singingi, seperti: upacara pengangkatan penghulu, helat perkawinan, dan pesta panen (Putri, Tania Dwika, Noor Efni Salam, dan Yasir, 2020). Pertunjukan randai bisa juga dilakukan pada acara sunat rasul (khitanan), melayur jalur atau ulang tahun jalur, perayaan kemerdekaan, perpisahan pejabat daerah, upacara adat, atau menyambut tamu kehormatan, dan sebagainya.

Pertunjukan Randai Kuantan Singingi meliputi unsur cerita atau $k a b a$, lawak, tarian atau joget, musik, dan lagu. Tiap unsur tidaklah berdiri sendiri, tidak ada batas yang tegas dengan unsur yang lain sehingga unsur itu dapat bercampur dengan unsur lain (Hamidy, 1980:68).

Pertunjukan Randai Kuantan Singingi diatur oleh seorang "sutradara" yang memiliki keahlian dalam meramu cerita, mampu berpantun, dan menyajikan, serta mengatur jalan atau alur cerita randai tersebut. Dia seorang yang kreatif sekaligus memiliki kemampuan manajerial.

Cerita dalam randai dapat disajikan secara monolog dan atau dialog. Cerita ini ditampilkan dalam beberapa bagian. Bagian dari satu cerita dengan yang lain akan dijedakan dengan musik (instrumen dan lagu), serta tarian joget.

Suasana pertunjukan Randai Kuantan Singingi dibuat sangat cair dan akrab. Nyaris tak ada jarak antara pemain dan penonton. Bahkan pada saat-saat tertentu, penonton bisa berbaur dengan pemain, misalnya pada saat berjoget dan menyanyi. Suasana akrab dan gembira yang dimunculkan dalam pertunjukan randai memunculkan kerinduan bagi masyarakat Kuantan Singingi terhadap 
Jurnal Ilmu Budaya, Vol. 17, No. 2 Februari Tahun 2021

tradisi ini. Tidak mengherankan, pertunjukan ini tidak pernah sepi penonton.

Setiap grup atau kelompok Randai Kuantan Singingi umumnya memiliki susunan organisasi yang mempunyai tugas dan tanggung jawab masing-masing. Susunan organisasi itu terdiri atas ketua randai, induk randai (sutradara randai) atau disebut juga dengan pemimpin randai, anggota randai disebut juga dengan istilah anak randai. Anak randai ini ada yang bertugas sebagai pemain adegan, penari, atau penyanyi.

Randai ini dimainkan oleh pemeran utama yang akan bertugas menyampaikan cerita. Pemeran utama ini bisa berjumlah satu orang, dua orang, tiga orang atau lebih tergantung dari cerita yang dibawakan. Dalam membawakan atau memerankannya pemeran utama dilingkari oleh anggota-anggota lain yang bertujuan untuk menyemarakkan berlangsungnya acara tersebut.

Karakter pemain yang menarik dalam Randai Kuantan Singingi adalah Bujang Gadi. Menurut (Putri, Salam dan Yasir (2020) Bujang Gadi merupakan tokoh laki-laki yang memerankan tokoh perempuan di dalam cerita randai. Mereka menggunakan kostum perempuan, berkaca mata hitam, dan menggunakan bandana yang berbunga-bunga di atas kepalanya. Selain itu, ada pula karakter lucu yang dimainkan oleh salah seorang anak randai. Tokoh ini disenangi penonton karena dapat mengundang tawa dan menyemarakkan suasana.

\section{Peta Persebaran Randai di Kabupatan Kuantan Singingi}

Tradisi berandai hidup di berbagai daerah di masyarakat Kuantan Singingi. Semua kecamatan yang ada di Kabupaten Kuantan Singingi pernah memiliki grup randai. Menurut Syaifudin (Pegawai Dinas Pariwisata Kabupaten Kuantan Singingi), di Kabupaten Kuantan Singingi diperkirakan ada 170 grup randai yang tersebar di setiap kecamatan yang ada di wilayah Kabupaten Kuantan Singingi. Akan 
Jurnal Ilmu Budaya, Vol. 17, No. 2 Februari Tahun 2021

tetapi, sekarang ini, tidak semua grup

randai ini masih eksis keberadaannya.

Untuk keperluan pemetaan

randai di dalam tulisan ini, terinventarisasi 47 grup randai. Grup randai tersebut yang akan dipetakan berdasarkan desa grup randai tersebut berada.

Daerah yang paling hulu adalah Kecamatan Hulu Kuantan. Di kecamatan ini terinventarisasi ada tiga grup randai, yaitu: (1) Randai Mustika (Koto Kombu), (2) Randai Tuah Sekato (Serosa), dan (3) Randai Bungo Serumpun (Tanjung Medan). Sementara, di Kecamatan Kuantan Mudik terdapat grup (1) Randai Na'im (Bukit Kauman), (2) Randai Marjani (Air Buluh), dan (3) Randai SMKN 1 Kuantan Mudik (Lubuk Jambi). Di Kecamatan Gunung Toar ada dua grup randai (1) Randai Tunas Muda, dan (2) Randai Batang Sianik SMAN 1 Gunung Toar (Gunung Toar). Ketiga kecamatan ini dahulunya tergabung ke dalam Kecamatan Kuantan Mudik.

Lebih ke hilir, terdapat Kecamatan Kuantan Tengah. Di kecamatan ini terdata delapan grup randai, yaitu : (1) Randai Kopah Sepakat, (2) Randai Nayan Bergoyang (Pulau Aro), (3) Randai Induak-Induak (Pulau Aro), (4) Randai Alibaba (Duik Abi Kuliah Tak Jadi) (Kopah), (5) Randai (Erdi) (Pulau Kedundung) (6) Randai (Yusril) (Seberang Taluk Hilir), dan (7) Randai (Azrianto) (Pulau Aro), dan (8) Randai (Jusman) (Koto Taluk). Di Kecamatan Sentajo Raya tercatat tiga grup randai, yaitu: (1) Randai Parit Teratak Air Hitam (Teratak Air Hitam), (2) Randai (Teratak Air Hitam), (3) Randai Elpis (Pulau Kopung). Adapun di Kecamatan Pangian, ditemukan ada lima grup randau, yaitu: Randai di Pauh Angit (Nuramin), Randai di Rengas (Simut), Randai di Tanah Bekali (Mistoni), Randai di Padang Kunyik (Mustapah), dan randai di Pulau Dore (Sahril).

Kecamatan Benai memiliki enam grup randai, yaitu: (1) Randai Banjar Benai (Banjar Benai) (2) Randai Benai Kecil (Parit Teratak Air Hitam) (3) Randai Pulau Ingu (Pulau Ingu), (4) Randai Banjar Lopak (Banjar Lopak), (5) Randai Talontam (Talontam), dan 
Jurnal Ilmu Budaya, Vol. 17, No. 2 Februari Tahun 2021

(6) Randai Ujung Tanjung (Ujung Tanjung).

Di Kecamatan Kuantan Hilir terdata empat grup randai, yaitu: (1) Randai Candra Kelana (Pasar Usang), (2) Randai Dendang Maimbau (Pasar Baru), (3) Randai Terang Bulan (Kampung Medan), dan (4) Randai Rentak Bulian (Tabalai), sedangkan di Kecamatan Kuantan Hilir Seberang terdapat empat grup randai: Randai Goyang Basamo (Pelukahan), Randai Koto Rajo (Koto Rajo), Randai "Nilam Sari" Banjar Nan Tigo (Isus), dan Randai "Sinar Muda" Banjar Nan Tigo (Ision).

Di Kecamatan Inuman Randai ada Randai Dendang Duduk (Banjar Inuman), Randai Mekar Sejati (Pulau Busuk Jaya), Randai Tunas Harapan (Koto Inuman), Randai Duduk (Pulau Sipan), Randai Bunga Setangkai (Sigaruntang), Sinar Muda (Banjar Nan Tigo), Nilam Sari (Banjar Nan Tigo), Bina Remaja (Sigaruntang). Di kecamatan yang berbatasan dengan Kabupaten Indragiri Hulu, Kecamatan Cerenti, ada dua grup randai yang diketahui, yaitu Randai "Tunas
Harapan" Koto Inuman (Pian) dan Randai "Bina Remaja" Desa Sigaruntang (Saril). Sementara di Kecamatan Singingi hanya tercatat satu grup randai, yaitu: Randai M. Nasir (Singingi).

Keberadaan dan persebaran grup-grup randai ini di Kabupaten Kuantan Singingi ini dimasukkan ke dalam peta persebaran randai berikut.

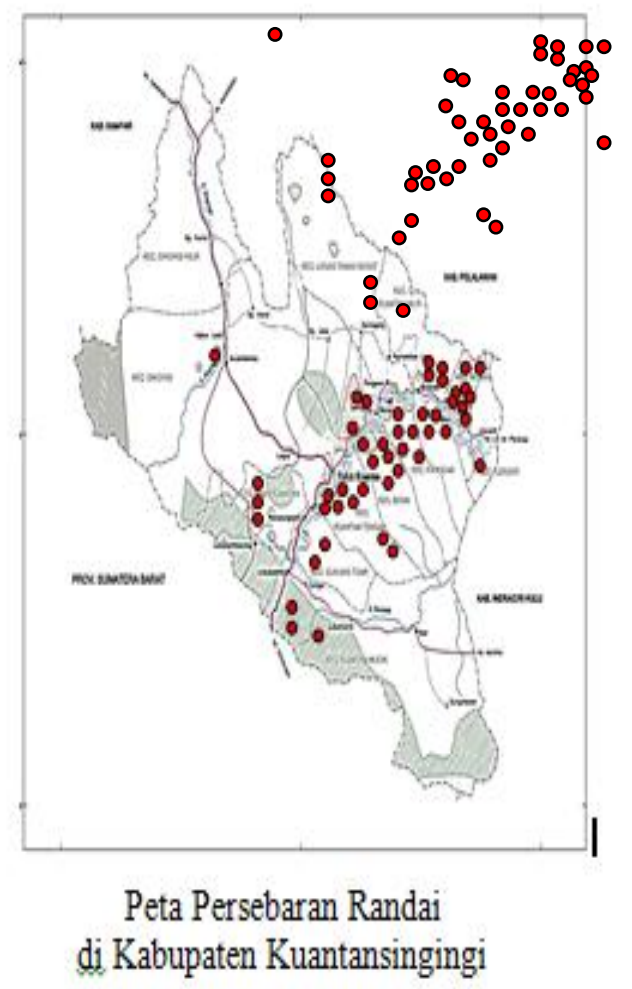

\section{Penutup}

Dari uraian sebelumnya, diketahui bahwa Randai Kuantan 
Jurnal Ilmu Budaya, Vol. 17, No. 2 Februari Tahun 2021

Singingi berasal dari Randai

Minangkabau yang sudah mengalami

perubahan. Akulturasi budaya

Minangkabau dengan Melayu dan

perubahan zaman memunculkan

perubahan pada cerita, bahasa, kostum,

tarian (joget), alat musik, dan waktu

pertunjukan.

Inventarisasi terhadap grup randai di Kabupaten Kuantan Singingi memperlihatkan bahwa randai merupakan tradisi yang ada di hampir seluruh daerah di Kabupaten Kuantan Singingi, Riau. Di dalam penelitian ini, randai dari Kecamatan Pucuk Rantau, Kecamatan Singingi Hulu dan Hilir, serta Kecamatan Logas Tanah Darat tidak terdata. Namun ditengarai bukan berarti tidak ada randai di daerah tersebut.

Tradisi randai merupakan salah satu tradisi yang hidup dan diminati masyarakat Kuantan Singingi. Oleh karena itu, pembuatan Peta Persebaran Randai di Kabupaten Kuantan Singingi, Provinsi Riau ini dapat bermanfaat bagi upaya pelindungan tradisi ini di masa yang akan datang.

\section{Daftar Pustaka}

Asrif. 2014. "Identifikasi, Pemetaan, dan Pelindungan Sastra Lokal Sulawesi Tenggara" dalam Jurnal Kandai Vol. 10, No. 1, Mei 2014; 127-137

http://ojs.badanbahasa.kemdikbud.g o.id/jurnal/index.php/kandai/article/ viewFile/317/136.

Muslim. 2006. "Laporan Akhir Pengkajian Teater Tradisi Randai Kuantan (Kajian Seni Pertunjukan) di Kabupaten Kuantan Singingi Provinsi Riau". Pekanbaru: Balai Pengkajian dan Pelatihan, Dinas Kebudayaan Kesenian dan Pariwisata Provinsi Riau.

Mulyani, Fitri dan Pairus Meidiani. 2020. Statistik Daerah Kabupaten Kuantan Singingi 2020. Telukkuantan: Badan Pusat Statistik Kabupaten Kuantan Singingi dan CV M\&N Grafika.

Hamidy, UU. 1980. "Randai dalam Kehidupan Masyarakat Melayu Riau". Tesis pada University Malaysia.

Harimansyah, Ganjar. 2019. Pedoman Penelitian Pemetaan Sastra. Jakarta: Badan Pengembangan Bahasa dan Perbukuan, Kementerian Pendidikan dan Kebudayaan.

Hidayat, Hada. 2014. "Nilai Budaya, Cerita Rakyat, Tradisi, Lisan Randai." Tesis pada Sekolah Pasca Sarjana Pendidikan 
Jurnal Ilmu Budaya, Vol. 17, No. 2 Februari Tahun 2021

Bahasa Indonesia S-2 dalam http://repository.upi.edu/id/eprint 19568.

Jufrizal. 2018. Pemetaan dan Kajian Bahasa dan Sastra Daerah: Pendokumentasian dan Perevitalisasian dalam http://repositori.kemdikbud.go.id 19965/1/dokumen_makalah_154 0534250.pdf. Makalah disajikan pada Kongres Bahasa Indonesia XI-tahun 2018 di Jakarta, 28 31 Oktober 2018.

Misrawati dan Sulaiman. 2020. "Transformasi Bujang Gadih At Randai's Show Teluk Kuantan, Provinsi Riau". Jurnal Ekspresi Seni: Jurnal Ilmu Pengetahuan dan Karya Seni Vol. 22, No 2 (2020) dalam https://journal.isi- padangpanjang.ac.id/index.php /Ekspresi/article/view/1012/58 3.

Putri, Tania Dwika, Salam, Noor Efni, dan Yasir. "Makna Kesenian Rakyat pada Masyarakat Kuantan Singingi Provinsi Riau (Studi Etnografi Komunikasi Randai Kuantan Riau)" dalam Jurnal Ilmu Komunikasi. Vol 9, No 3 (2020). https://jkms.ejournal.unri.ac.id/in dex.php/JKMS/article/view/7389 $\underline{16479}$.

Wendy, HS. 2014. "Dramaturgi Teater Rakyat Randai di Minangkabau" dalam Jurnal Kajian Seni, Vol. 01, No. 01, November 2014 dalam jurnal.ugm.ac.id/jks/article/dow nload/5874/4759. 